\title{
Edukasi Perilaku Hidup Bersih Dan Sehat Dalam Pencegahan Penyebaran Covid-19 Di Masyarakat Kota Malang
}

\author{
Bintari Ratih Kusumaningrum ${ }^{1}$, Ayunda Dewi Jayanti Jilan Putri ${ }^{2}$, Aurick Yudha Nagara ${ }^{3}$, \\ Akhiyan Hadi Susanto ${ }^{1}$, Ika Setyo Rini ${ }^{1}$, Ikhda Ulya ${ }^{1}$, Eriko Prawestiningtyas ${ }^{4}$, Muhammad \\ Satria Herdiyono ${ }^{5}$, Agustinus Lorensa Krisyanto ${ }^{5}$, Mutiaranti Nainggolan ${ }^{5}$ \\ ${ }^{1}$ Jurusan Keperawatan Fakultas Kedokteran Universitas Brawijaya \\ ${ }^{2}$ Lab Ilmu Kesehatan Masyarakat Fakultas Kedokteran Universitas Brawijaya \\ 3. Lab. Kedokteran Emergensi Medisin Fakultas Kedokteran Universitas Brawijaya \\ 4. Lab Kedokteran Forensik Fakultas Kedokteran Universitas Brawijaya \\ 5. Mahasiswa Program Studi S1 Keperawatan Jurusan Keperawatan Fakultas Kedokteran Universitas \\ Brawijaya \\ *e-mail: bintariratih@ub.ac.id/085785222289
}

\begin{abstract}
Abstrak
Pencegahan penyebaran Covid-19 ini tidak bisa hanya dengan tenaga kesehatan saja yang berperan, namun dibutuhkan kerjasama lintas sector. Unsur yang terlibat adalah pemerintah, masyarakat, dunia usaha, akademisi, dan media. Agar pencegahan di masyarakat dapat berjalan dengan baik maka harus ada tokoh atau kader kesehatan yang aktif melakukan promosi kesehatan pencegahan Covid-19. Program pengabdian masyarakat kampong tangguh ini bertujuan untuk memberikan edukasi perilaku hidup bersih dan sehat untuk mencegah penularan COVID-19 kepada kader kesehatan di masyarakat. Metode yang digunakan dalam program pengabdian masyarakat ini adalah pemberian intervensi pada masyarakat dengan pendekatan post tes only terhadap 76 partisipan kader kesehatan di 8 kelurahan di Kota Malang. Media yang digunakan untuk edukasi adalah poster PHBS dan praktik langsung. Hasil yang didapatkan yaitu skor pengetahuan PHBS 74,21 dari skor maksimal 100dan skor observasi perilaku 26,53 dari skor maksimal 30. Sebagian besar sudah ada sarana untuk PHBS namun dalam pelaksanaan protocol kesehatan masih kurang. Dapat disimpulkan bahwa kegiatan ini membawa dampak positif bagi kader dan masyarakat luas karena akademisi turun langsung memberikan contoh PHBS.
\end{abstract}

Kata kunci: Pencegahan, Covid-19, Perilaku hidup bersih dan sehat, Kader.

\begin{abstract}
Preventing the spread of Covid-19 cannot only be done by health workers who play a role, but it requires cross-sector cooperation. The elements involved are the government, society, business world, academia, and the media. In order for prevention in the community to run well, there must be health figures or cadres who are active in promoting Covid-19 prevention health. This community service program aimed to provide education on clean and healthy living habits to prevent transmission of COVID-19 to health cadres in the community. The method used in this community service program is the provision of intervention to the community with a post-test only approach to 76 health cadre participants in 8 villages in Malang City. The media used for education are PHBS posters and hands-on practice. The results obtained are a score of PHBS knowledge of 74.21 from a maximum score of 100 and a score of behavioral observation of 26.53 from a maximum score of 30. Most of them already have facilities for PHBS but the implementation of health protocols is still lacking. It can be concluded that this activity had a positive impact on cadres and the wider community because academics came directly to provide examples of PHBS.
\end{abstract}

Keywords: Prevention, Covid-19, Behavior of clean and healthy living, Cadres.

\section{PENDAHULUAN}

Coronavirus Disease 2019 (COVID-19) adalah penyakit jenis baru yang belum pernah diidentifikasi sebelumnya pada manusia. Virus penyebab COVID-19 ini dinamakan Sars-CoV-2. Pada tanggal 30 Januari 2020 WHO telah menetapkan sebagai Kedaruratan Kesehatan Masyarakat Yang Meresahkan Dunia/ Public Health Emergency of International Concern (KKMMD/PHEIC). Penambahan jumlah kasus COVID-19 berlangsung cukup cepat dan sudah terjadi penyebaran antar negara. 
Covid-19 atau Corona Virus disease 19 telah menginfeksi 216 negara di dunia. Menurut data terakhir dari WHO 25 mei 2020 kasus terkonfirmasi mencapai 5,3 juta, meninggal 342.070 kasus. Sedangkan di Indonesia per 25 Mei 2020 kasus positif sebanyak 22.750, sembuh 5.642, dan meninggal 1.391 (Gugus Tugas Percepatan penanganan Covid-19, 2020). Virus ini merupakan virus baru yang sangat mudah menyebar sehingga dapat menginfeksi orang dalam jumlah besar dan sudah berdampak secara global sehingga disebut Pandemi.

Berdasarkan bukti ilmiah, COVID-19 dapat menular dari manusia ke manusia melalui percikan batuk/bersin (droplet), tidak melalui udara. Orang yang paling berisiko tertular penyakit ini adalah orang yang kontak erat dengan pasien COVID-19 termasuk yang merawat pasien COVID-19. Rekomendasi standar untuk mencegah penyebaran infeksi adalah melalui cuci tangan secara teratur menggunakan sabun dan air bersih, menerapkan etika batuk dan bersin, menghindari kontak secara langsung dengan ternak dan hewan liar serta menghindari kontak dekat dengan siapapun yang menunjukkan gejala penyakit pernapasan seperti batuk dan bersin (Kemenkes, 2020).

Pencegahan ini tidak bisa hanya dengan tenaga kesehatan saja yang berperan, namun dibutuhkan kerjasama lintas sektor karena pandemi ini sudah ditetapkan sebagai bencana nasional. Kerjasama tersebut disebut Pentahelix dalam penanganan bencana. Unsur yang terlibat adalah pemerintah, masyarakat, dunia usaha, akademisi, dan media. Dalam menangani pendemi ini, pemerintah telah membentuk gugus tugas percepatan penanganan Covid. Dalam pencegahan ini pemerintah bertugas untuk melakukan komunikasi risiko kepada masyarakat melalui media cetak maupuan elektronik (Gugus Tugas Percepatan penanganan covid-19, 2020).

Komunikasi risiko dan pemberdayaan masyarakat (KRPM) merupakan komponen penting yang tidak terpisahkan dalam penanggulangan tanggap darurat kesehatan masyarakat, baik secara lokal, nasional, maupun internasional. KRPM dapat membantu mencegah infodemic (penyebaran informasi yang salah/hoaks), membangun kepercayaan publik terhadap kesiapsiagaan dan respon pemerintah sehingga masyarakat dapat menerima informasi dengan baik dan mengikuti anjuran pemerintah. Dengan demikian, hal-hal tersebut dapat meminimalkan kesalahpahaman dan mengelola isu/hoaks terhadap kondisi maupun risiko kesehatan yang sedang terjadi (Kemenkes, 2020).

Universitas Brawijaya sebagai instansi pemerintah dan juga akademisi ikut berperan serta dalam pencegahan dengan memberikan edukasi kepada masyarakat. Universitas Brawijaya telah menginisiasi adanya Kampung Tangguh untuk memberdayakan dan menguatkan masyarakat. Kampung Tangguh dibentuk setingkat RW. Di dalamnya terdapat kegiatan untuk memperuat masyarakat dalam bidang informasi dan kesehatan. Masyarakat harus ikut berperan penting dalam tindakan pencegahan penyebaran covid-19 agar masalah kesehatan ini cepat selesai (Satgas Covid-19 UB, 2020).

Agar pencegahan di masyarakat dapat berjalan dengan baik maka harus ada tokoh atau kader kesehatan yang aktif melakukan promosi kesehatan pencegahan Covid-19. Promosi kesehatan terhadap kader merupakan juga bagian dari komunikasi masyarakat (Kemenkes, 2020). Kader kesehatan tersebut harus memiliki pengetahuan yang adekuat, kepercayaan diri yang bagus, serta dapat menjadi contoh yang baik bagi masyarakat. Sayangnya tidak semua kader memiliki hal tersebut. Dengan adanya kampung tangguh maka kader kesehatan yang memiliki motivasi tinggi dapat di kelola dan diberikan materi edukasi promosi kesehatan pencegahan Covid-19. Program pengabdian masyarakat kampong tangguh ini bertujuan untuk memberikan edukasi perilaku hidup bersih dan sehat untuk mencegah penularan COVID-19 kepada kader kesehatan di masyarakat. Dengan harapan kader tersebut dapat menularkan kepada masyarakat yang lebih luas.

BAHAN DAN METODE (TNR 12 point, Bold, spasi 1,5)

Metode yang digunakan dalam program pengabdian masyarakat ini adalah pemberian intervensi pada masyarakat dengan pendekatan post tes only terhadap 76 partisipan kader 
kesehatan. Sebelum diberikan kuesioner tim pengabdian juga mengobservasi perilaku dan wawancara kepada kader. Pengukuran keberhasilan kegiatan menggunakan kuesioner yang berisi pengetahuan tentang covid dan PHBS serta lembar observasi perilaku yang telah di uji validitasnya pada 20 orang kader kesehatan di kelurahan kotalama dan sukoharjo. Teknik analisis data menggunakan analisis deskriptif dengan distribusi frekuensi untuk data demografi dan menggunakan data rata-rata untuk skor pengetahuan. Lokasi pengabdian masyarakat di 8 kelurahan Kota Malang yaitu keluarahan Kasin, Lowokwaru, Penanggungan, sumbersari, kiduldalem, tasikmadu, merjosari, dan tlogomas. Waktu kegiatan selama 3 bulan yaitu April-Juni 2020.

Pelaksanaan kegiatan edukasi promosi kesehatan ini diawali dengan pembuatan konten edukasi dan medianya. Setelah itu dilakukan koordinasi dengan kader yang ada di Kampung Tangguh. Dalam koordinasi tersebut tim satgas memberikan arahan untuk pelaksanaanya agar sesuai dengan protokol kesehatan yaitu jarak pengaturan tempat duduk, di sediakan sarana untuk cuci tangan baik dengan hand sanitizer atau sabun dan air mengalir serta kader yang hadir wajib menggunakan masker.

Media yang digunakan untuk edukasi adalah konten edukasi dari Promosi kesehatan Kemenkes 2020 serta leaflet yang dicetak dan disebarkan melalui whatsapp ke kader. Proses edukasi diawali dengan mengeksplorasi sejauh mana pengetahuan warga dalam melakukan cuci tangan, menggunakan masker, melakukan physical distancing serta etika batuk. Hal ini dilakukan dengan menggunakan kuesioner yang telah dibuat oleh tim satgas berdasarkan dari pedoman pengendalian dan pencegahan covid-19 dari kemenkes Revisi ke 4. Selain kuesioner juga dilakukan wawancara serta observasi oleh tim.

Setelah eksplorasi dan observasi perilaku mereka, maka tim melakukan penyuluhan tentang alasan-alasan rasional mengenai mengapa protocol kesehatan harus diterapkan. Penyuluhan dilakukan selama 30 menit. Setelah itu tim mempraktikkan prosedur cuci tangan 6 langkah menggunakan sarana yang sudah disiapkan selama 30 menit. Praktik ini tidak hanya demonstrasi saja tetapi juga di ikuti oleh warga sehingga mereka dapat langsung praktik dan fasilitator atau tim satgas mengobservasi dan langsung membenarkan ketika ada yang salah.

\section{HASIL}

Hasil kegiatan berupa hasil analisis deskripsi dari kuesioner yang meliputi data demografi dan deskripsi pengetahuan PHBS, obervasi perilaku, dan deskripsi kegiatan yang dilakukan oleh tim satgas dan kader kesehatan.

Data demografi

Data demografi ditampilkan di tabel 1. Dari tabel 1 tersebut dapat diketahui setengah dari kader adalah laki-laki, status pernikaha menikah, sebaran pekerjaan adalah swasta dan tidak bekerja. Sedangkan usia rata-rata kader adalah 44 tahun dengan usia minimal 19 tahun dan paling tinggi adalah 70 tahun.

Hasil observasi perilaku dan wawancara

Hasil pengamatan di 8 kelurahan tersebut tampak bahwa sebagian warga telah mengenakan masker namun sebagian belum, belum melaksanakan jaga jarak minimal 1 meter, atau masih bekerumun. Dari hasil observasi terkait cuci tangan, Dari observasi lingkungan sekitar warga, telah ada sarana untuk cuci tangan dan juga ada pengaturan jarak ketika ada acara edukasi. Namun masih ada yang tidak bisa cuci tangan 6 langkah. Mereka hanya cuci tangan biasa asal basah dan asal terkena sabun.

Deskripsi pengetahuan PHBS

Data yang didapatkan dari 76 responden di tampilkan di tabel 2. Hasil dari kuesioner menjukkan bahwa rata rata-rata skor pengetahuan warga adalah 74, 21 dari skor maksimal adalah 100 , hal ini menunjukkan pengetahuan sudah baik setelah diberikan edukasi. Dalam hal keterampilan, sebelum dilakukan edukasi masih ada yang belum melakukan dengan benar, tetapi setelah diberi edukasi dan memberi contoh langsung mereka sudah bisa melakukan 
dengan benar. Hal ini ditunjukkan dengan nilai skor observasi perilaku rata-ratanya 26,53 dengan nilai maksimal 30 .

\section{PEMBAHASAN}

Kader yang mengikuti kegiatan ini sangat antusias walaupun usia sudah sangat lanjut karena pada masa pandemic akan banyak menyebabkan ketidakjelasan informasi. Sehingga kegiatan ini bisa memfasilitasi transfer pengetahuan kepada mereka secara langsung. Mereka diberikan edukasi oleh para akademisi sehingga informasi yang didapatkan lebih jelas. Edukasi kesehatan PHBS di fokuskan pada pemberian alasan rasional cuci tangan yang benar dan mempraktikkan cuci tangan 6 langkah dengan benar.

Wawancara pada sebagian warga menunjukkan bahwa warga sudah menerapkan protocol kesehatan tetapi tidak semuanya karena ada keterbatasan misalnya ketika berbelanja tidak sempat untuk menjaga jarak, atau ketika dari luar rumah ada yang tidak langsung mandi dan berganti baju. Untuk pembatasan aktivitas berkumpul sudah dilakukan denagn cara meniadakan sementara kegiatan dasawisma, arisan PKK, dan posyandu Balita. Untuk mengatasi hal tersebut mereka atau kader kesehatan sudah melakukan posyandu Balita dengan tetap menimbang balita dengan datang kerumah masing-masing Balita untuk mengukur status gizi dan tumbuh kembangnya tentunya dengan memperhatikan protocol kesehatan.

Hasil observasi juga menunjukkan bahwa masyarakat sangat antusias mengikuti kegiatan promosi kesehatan ini, dengan rentang usia yang mengikuti adalah 19-70 tahun. Walaupun sudah usia lanjut, warga tersebut sangat aktif bertanya dan berbagi cerita tentang apa yang mereka lakukan dalam mematuhi protokol kesehatan. Antusiasme tersebut menunjukkan bahwa mereka tertarik dan termotivasi untuk menjadi kader. Selain itu mereka juga mengungkapkan bahwa kondisi pandemic ini adalah kondisi yang baru mereka alami, sehingga mereka ada semangat untuk mengetahui hal baru yaitu pencegahan penyebaran covid-19 di wilayah mereka.

Pengetahuan yang baik didapatkan oleh kader setelah mengikuti kegiatan ini. Melihat fenomena ini dapat disimpulkan bahwa pembelajaran hal baru dengan tujuan mengubah perilaku harus dilakukan secara langsung dan praktik langsung. Karena jika dilakukan secara dalam jaringan (daring) akan banyak menimbulkan perbedaan persepsi. Pemberian edukasi secara langsung juga dapat memberikan kepercayaan kader bahwa tim satgas hadir sepenuhnya untuk mereka dan membantu mereka menjadi agen perubahan diwilayah kampong mereka. Dokumentasi kegiatan dapat dilihat di gambar 1.

Dari hasil tersebut menunjukkan bahwa edukasi secara langsung sangat bermanfaat bagi warga karena tim satgas dapat melihat secara langsung permasalahan yang mereka hadapi dan bisa memberi klarifikasi terkait berita berita yang kurang benar di media social. Selain itu dengan edukasi secara langsung akan membuat masyarakat lebih puas karena dapat menjawab keresahan mereka. Beberapa warga mengutarakan bahwa mereka cemas dengan pemberitaan yang ada di media social. Mereka juga takut tertular covid-19. Dengan tatap muka secara langsung mereka lebih lega dan lebih percaya diri dalam memberikan edukasi kepada keluarga mereka maupun masyarakat sekitar.

Namun pertemuan secara langsung ini juga terdapat kekurangan serta keterbatasan. Keterbatasan tersebut antara lain jika lokasinya sangat terbatas akan sulit untuk membuat jarak minimal 1 meter. Pengukuran pengetahuan dan praktik hanya dilakukan pada saat setelah edukasi hal ini terjadi karena kader tidak datang bersamaan di awal tetapi terkadang ada yang datang terlambat. Selain itu keterbatasan waktu karena penyuluhan dilakukan saat bulan puasa karena mengejar untuk persiapan PSBB di Malang Raya. Disamping itu tim satgas juga masih ada kewajiban pengajaran sehingga waktu penyuluhan dilakukan setelah proses pengajaran selesai yaitu diatas jam 13.00. Namun hal ini bisa diatasi dengan kedisiplinan tim dan kerjasama yang baik dengan masyarakat sehingga persiapan dan pelaksanaan bisa tercapai sesuai jadwal yang ditargetkan. 
Kegiatan edukasi promosi kesehatan tentang PHBS di kampung tangguh ini mendapat apresiasi yang sangat baik dari masyarakat. Setiap kegiatan ini juga di sampaikan secara daring dengan menggunakan zoom meeting dan di streaming melalui youtube sehingga prosesnya secara langsung bisa dilihat oleh masyarakat yang lebih luas jangkauanya. Salah satu Tautan youtube nya sebagai berikut https://www.youtube.com/watch?v=80K7i4npcbU. Didalam tautan tersebut terdapat SOP edukasi promosi kesehatan dalam bentuk audiovisual.

Hal ini juga diapresiasi oleh Gubernur Jawa tImur, beliau mengunjungi salah satu kampong tanguh di malang melihat persiapaannya dan beliau sangat mengapresiasi peran UB dalam memperkuat masyarakat. Sehingga oleh beliau Kampung Tangguh di terapkan di jawa timur untuk memperkuat masyarakat dalam pencegahan penyebaran Covid-19. Adanya publikasi yang sangat massif tentang edukasi promosi kesehatan di kampong Tangguh di Kota Malang di media online mendorong pimpinan daerah Kabupaten Malang dan Kota Batu ingin dilatih secara langsung untuk menyiapkan masyarakat dalam mencegah penyebaran covid-19 ini.

\section{KESIMPULAN DAN SARAN}

Dapat disimpulkan bahwa edukasi promosi kesehatan PHBS ini sangat bermanfaat untuk meningkatkan pengetahuan dan perilaku warga Kota Malang dalam melakukan pencegahan penyebaran Covid-19. Edukasi secara langsung juga dapat meningkatkan kepercayaan diri warga dalam berperan sebagai kader kesehatan untuk menularkan ilmunya ke warga yang lain. Selain itu juga memudahkan tim satgas untuk mengobservasi perilaku dan mendekatkan akademisi ke masyarakat. Masyarakat sebagai bagian dalam penanganan pandemic ini perlu didukung oleh pemerintah setempat, perangkat pemerintahan, dunia usaha dan akademisi agar menajdi lebih kuat. Karena dasar dari pencegahan penyakit adalah dari pemberdayaan masyarakat. Saat ini telah dilatih sebanyak 24 RW di kota Malang dan 2 RW di kabupaten Malang. Kegiatan ini akan terus bergulir hingga sampai di kabupaten malang

UCAPAN TERIMA KASIH (TNR 12 point, Bold, spasi 1,5)

Penulis mengucapkan terima kasih kepada pihak yang telah memberi dukungan terhadap pengabdian ini. Penulis mengucapkan terima kasih kepada Fakultas Kedokteran Universitas Brawijaya yang telah mendanai kegiatan ini. Selain itu kami juga mengucapkan terimakasih kepada Satgas Covid-19 Universitas Brawijaya, Tim pengembang Kampung Tangguh Universitas Brawijaya, Kader Kampung Cempluk Kecamatan Dau Kabupaten Malang yang telah menginisiasi kampong tangguh. Pemerintah Kota Malang, Polres Malang Kota, Kodim serta perangkat pemerintahan RT RW di wilayah Kota malang yang telah bekerjasama sehingga kegiatan pengabdian ini bisa terwujud dengan lancar.

\section{DAFTAR PUSTAKA}

Gugus tugas percepatan penanganan Covid-19. 2020. Sebaran kasus. https://covid19.go.id/peta-sebaran

Kemenkes. 2020. Pedoman Pencegahan dan pengendalian coronavirus disease (covid-19). https://covid19.kemkes.go.id/situasi-infeksi-emerging/info-corona-virus/dokumen-resmikesiapsiagaan-menghadapi-novel-coronavirus-covid-19-revisi-ke-4/\#.Xsy9Pmgza00

Satgas covid-19 UB. 2020. Buku Pedoman Kampung Tangguh edisi revisi 3.0. Universitas Brawijaya 
Bintari Ratih Kusumaningrum, Ayunda Dewi Jayanti Jilan Putri, Aurick Yudha Nagara, Akhiyan Hadi Susanto, Ika Setyo Rini, Ikhda Ulya, Eriko Prawestiningtyas, Muhammad Satria Herdiyono, Agustinus Lorensa Krisyanto, Mutiaranti Nainggolan

\section{LAMPIRAN}

1. Data demografi

Tabel 1. Data demografi kader

\begin{tabular}{|c|c|c|}
\hline Karakteristik & $F(n)$ & $\%$ \\
\hline \multicolumn{3}{|l|}{ Jenis kelamin } \\
\hline Laki Laki & 46 & 60.5 \\
\hline Perempuan & 30 & 39.5 \\
\hline Total & 76 & 100 \\
\hline \multicolumn{3}{|l|}{ Status pernikahan } \\
\hline Menikah & 53 & 69.7 \\
\hline Belum Menikah & 18 & 23.7 \\
\hline Janda/Duda & 5 & 6.6 \\
\hline Total & 76 & 100.0 \\
\hline \multicolumn{3}{|l|}{ Pekerjaan } \\
\hline Guru/Pengajar & 11 & 14.5 \\
\hline Wiraswasta & 6 & 7.9 \\
\hline Swasta & 14 & 18.4 \\
\hline $\begin{array}{l}\text { Ibu Rumah } \\
\text { Tangga }\end{array}$ & 11 & 14.5 \\
\hline Pedagang: & 4 & 5.3 \\
\hline Buruh & 3 & 3.9 \\
\hline Dosen & 4 & 5.3 \\
\hline Mahasiswa & 3 & 3.9 \\
\hline ASN & 1 & 1.3 \\
\hline Tidak Bekerja & 13 & 17.1 \\
\hline $\begin{array}{l}\text { DIl (Pegawai } \\
\text { Salon, Mudin, } \\
\text { Tukang Batu, } \\
\text { Satpam) }\end{array}$ & 6 & 7.9 \\
\hline Total & 76 & 100.0 \\
\hline
\end{tabular}

Tabel 2. Hasil analisis deskriptif skor pengetahuan tentang PHBS dan observasi perilaku PHBS

\begin{tabular}{|l|c|c|c|c|}
\hline & Rerata & Minimum & Maksimum & Std. deviasi \\
\hline PHBS & 74.21 & 40 & 100 & 13.393 \\
\hline
\end{tabular}


Bintari Ratih Kusumaningrum, Ayunda Dewi Jayanti Jilan Putri, Aurick Yudha Nagara, Akhiyan Hadi Susanto, Ika Setyo Rini, Ikhda Ulya, Eriko Prawestiningtyas, Muhammad Satria Herdiyono,

Agustinus Lorensa Krisyanto, Mutiaranti Nainggolan

\begin{tabular}{|l|c|c|c|c|}
\hline $\begin{array}{l}\text { Observasi } \\
\text { perilaku }\end{array}$ & 26.53 & 20 & 30 & 2.788 \\
\hline
\end{tabular}

1. Foto

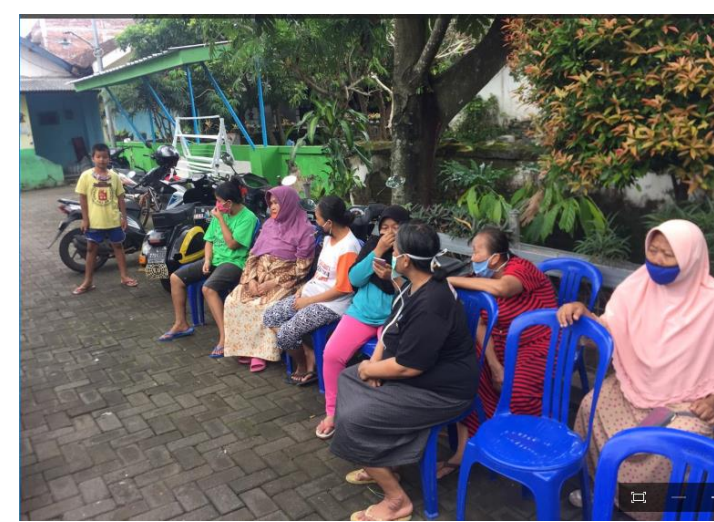

(a)

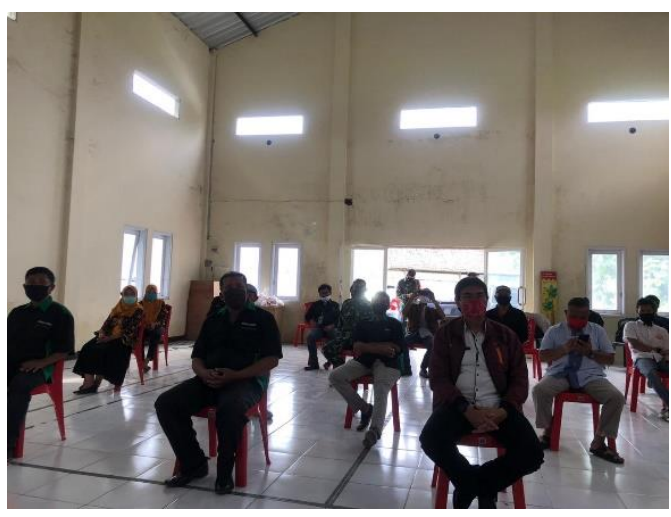

(b)

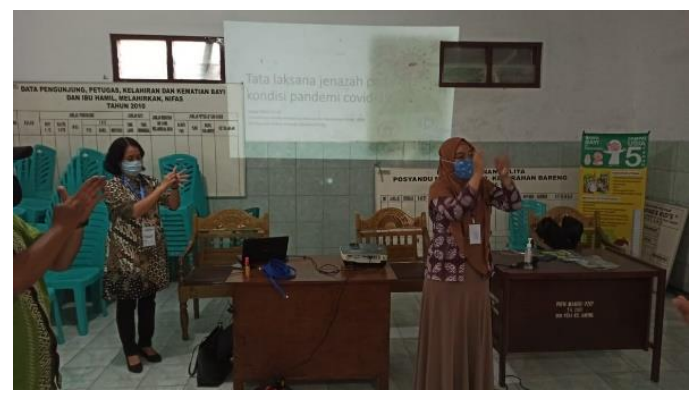

(c)

Gambar 1. Kegiatan edukasi (a) kader kesehatan pada saat belum menerapkan anjuran jaga jarak. (b) edukasi dengan jaga jarak (c) tim memberikan contoh cuci tangan 